\title{
Variations in Short Wave Radiation and Ocean Temperature in the Tropical Indian Ocean
}

\author{
Ahmad Fadlan ${ }^{1 *}$, Muchammad Rizki ${ }^{1}$, Tomi Ilham Pahlewi², Mohammad Ridwan Nur \\ Prasetyo $^{2}$, Fajar Masan Bali ${ }^{2}$, Imelda Umiyatul Badriyah ${ }^{2}$, Muhammad Aldi Lukman ${ }^{3}$

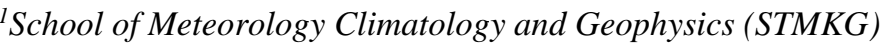 \\ Jl. Perhubungan I No. 5, Pondok Betung, Tangerang Selatan, Banten 15221 Indonesia \\ ${ }^{2}$ Meteorology, Climatology and Geophysical Agency (BMKG) \\ Jl. Angkasa 1 No.2, RW.10, Gn. Sahari Sel., Jakarta Pusat, Daerah Khusus Ibukota Jakarta 10610 Indonesia \\ ${ }^{3}$ Marine Meteorological Station of Pontianak \\ Komplek Pelabuhan Dwikora, Jalan Pelabuhan Laut Pontianak, Pontianak, Kalimantan Barat, 78112 Indonesia \\ Email: ahmad.fadlan@stmkg.ac.id
}

\begin{abstract}
The purpose of this study was to know the results of the relation between short wave radiation (SWR) and sea temperature. This study used data of SWR and sea temperature from RAMA buoy which part of the data was obtained by the INA-PRIMA 2019. Besides, the SWR and Sea Temperature model data from ERA-5 and Copernicus were required to see these spatial and temporal variations. Diurnal analysis to determine the sea temperature responds to SWR parameters. While monthly analysis to see the variations of SWR and the sea temperature during Indian Ocean Dipole (IOD). The results show that there is a different response at sea temperature for each layer to the SWR parameter in diurnal. SWR can affect sea temperatures until 20 meters of depth. There is a time lag between 2 and 3 hours when the sun heats the sea until the sea surface temperature increases. The 20 meters of depth has a lag time until 4 hours. As for 40 to 80 meters of depth, the sea temperature was not longer responded by SWR, and the temperature is changed by the strength of these mixing. Warm pools are generally located in East Indian Ocean and the high SWR were very strong in West Indian Ocean along an anual.
\end{abstract}

Keywords : Short wave Radiation, Sea Temperature, Indian Ocean

\section{INTRODUCTION}

Solar radiation is the main source of energy in human life on earth. Solar radiation is emitted by electromagnetic waves which have different wavelengths. However, from the wave spectrum, the sun's heat enters the earth's surface in infrared, visible and ultraviolet light (Kalogirou, 2009). Solar radiation that entering to the earth is known as short wave radiation (SWR). The amount of acceptance of SWR varies widely, both spatially and temporally, but is almost constant in the upper atmosphere of the earth. Temporally, solar radiation is highly represented by the motion of the sun which shows the receiving of heat at every latitude on earth. This shows the difference in seasons and weather in several regions of the earth. In addition, there is a filter in the atmosphere due to scattering and absorption by airborne particles such as dust, aerosols and water vapor. (Klassen \&
Bugbee, 2005). Most of the radiation that reaches the surface will be absorbed by land and oceans and becomes an important part of the process on the surface. Absorption by the ocean surface will certainly cause sea surface temperatures to increase and is the basis of ocean circulation and the process of hydrological circulation (Wild and Liepert, 2010)

Sea temperature in general is very dependent on radiation from the sun, especially in the surface area (Huang et al., 2018). It's the reason why is sea surface temperatures generally warmer near the equator than in areas at higher latitudes. Sea surface temperature is an important part of understanding ocean-atmosphere interactions. The seasonal, inter-year, and long-term sea surface temperature variations are very important in the process of climate change and the formation of global phenomena, one of which is the Indian 
Ocean Dipole (IOD) (Sukresno, 2010) (Manjunatha et al., 2015) (Dewi et al., 2020) (Putra et al., 2020). The sea surface temperature has a role in determining the Dipole Mode Index (DMI) where the positive and negative IOD phases depend on the anomalous conditions of sea surface temperature in the west and east of the Indian Ocean (Saji et al., 1999).

To understand the relationship of SWR and SST in the Indian Ocean, this research will conduct a study of daily patterns between SWR and SST at several points in the observation of mooring buoy which is part of INA-PRIMA 2019 program. Furthermore, monthly and seasonal variations conducted to understand the relationship between the two parameters and their relation to the IOD phenomenon.

\section{MATERIAL AND METHOD}

This study is part of the INA-PRIMA 2019 program which aims to understand the dynamics and interactions of oceans and the atmosphere in the Indian Ocean region. The used data in this study are part of the mooring buoy observation data that was deployed through the INA-PRIMA 2019 program at $8^{\circ} \mathrm{N} 90^{\circ} \mathrm{E}$ and $5^{\circ} \mathrm{S} 95^{\circ} \mathrm{E}$ points (Figure 1). Point sampling based on the availability of data as well as those approaching the equatorial region of the Indian Ocean. Furthermore, the parameters used are short wave radiation $\left(\mathrm{W} / \mathrm{m}^{2}\right)$ from the observation of the pyranometer sensor and sea temperature $\left({ }^{\circ} \mathrm{C}\right)$ on the surface layer and depths of $20,40,60$ and $80 \mathrm{~m}$. Selection of the depth of sea water to understand how deep solar radiation can directly affect changes in temperature in each layer. All data used in the study can be accessed on the pmel.noaa.gov page on the RAMA buoy research mission (Figure 1).

This study also uses data from several ocean and atmospheric models to cover empty or missing observation points at several mooring buoy observation points in the Indian Ocean. In addition, the used model is also to understand the monthly and seasonal variations between SWR and SST both spatially and points and their relation to the IOD phenomenon. The used model data in this study is sea surface temperature data sourced from marine.copernicus.eu with a spatial resolution of $0.08^{\circ}$. Downward short wave radiation flux (DSWR) data sourced from ERA-5 ECMWF with $0.25^{\circ}$ spatial resolution. The use of downward short wave radiation flux in this study is because the approach used in this model is like the observations of the pyranometer on the earth's surface (ERA-5 document). Spatial analysis uses Grid Analysis and Display (GRADS) and Integrated Data Viewer (IDV) applications.

All model data will be tested first to determine the accuracy of the model as a representative of the observations. Tests are carried out with simple comparisons and statistical correlation analysis. Correlation analysis is also used to determine the relationship between the DMI in the east and west of Indian Ocean against the SWR data in those regions.

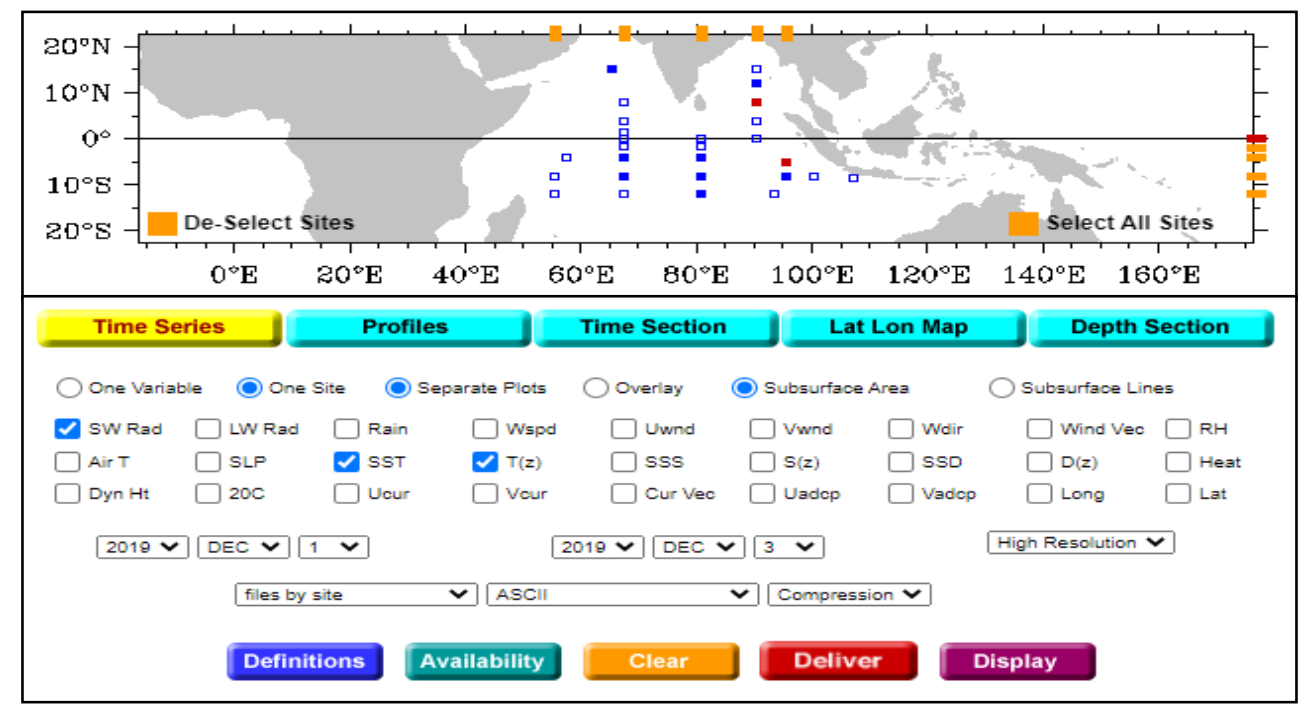

Figure 1. The location of mooring buoy that use in this study (red plot on maps) and Display of pmel.noaa.gov where data is available for free deliver. 


\section{RESULTS AND DISCUSSION}

The SWR observation results at two buoy observation points (Figure 2), in general it shows a slightly different SWR value, where in the southern region $\left(5^{\circ} S 95^{\circ} \mathrm{E}\right)$ has a higher $S W R$ value reaching $1000 \mathrm{~W} / \mathrm{m}^{2}$ while in the northern equatorial region $\left(8^{\circ} \mathrm{N} 90^{\circ} \mathrm{E}\right)$ it has a SWR only reaches $800 \mathrm{~W} / \mathrm{m}^{2}$. This difference is due to the apparent position of the sun in the southern region during December, so that the SWR distance is closer to the south than north of the equator. This condition will result in a lot of SWR absorption and scattering to the surface in the northern equatorial region. However, the SWR daily pattern generally shows the same pattern with the SWR peak were occurring at 4 - 6 UTC.

Based on the daily SWR pattern, an approach was made with the daily pattern of sea temperature starting from the surface layer to a depth of $80 \mathrm{~m}$ (Figure 2). In general, it appears that the surface layer is very responsive to the increase in SWR with an increase in SST with a lag time of about 2-3 hours. It is similar in the Pacific Ocean (Huang et al., 2018). In the 20 meter layer, the sea in general still responds to an increase in SWR with an increase in sea temperature with a lag time of about 4 hours from the daily peak of the SWR. This condition can be clearly seen at the observation point south of the equator (Figure 2a). conditions that are slightly different from the results of observations of sea temperature in the northern equatorial region (Figure $2 b$ ) where changes in sea temperature from the surface to a depth of $80 \mathrm{~m}$ have more dynamic changes. Based on research (de Boyer Montégut et al., 2004) shows several factors that influence the mixing layer such as wind stress, internal waves and currents. On the other hands, wind speed is also given the impact on the difference in heat reception on the sea surface, where the stronger wind make the lower SST

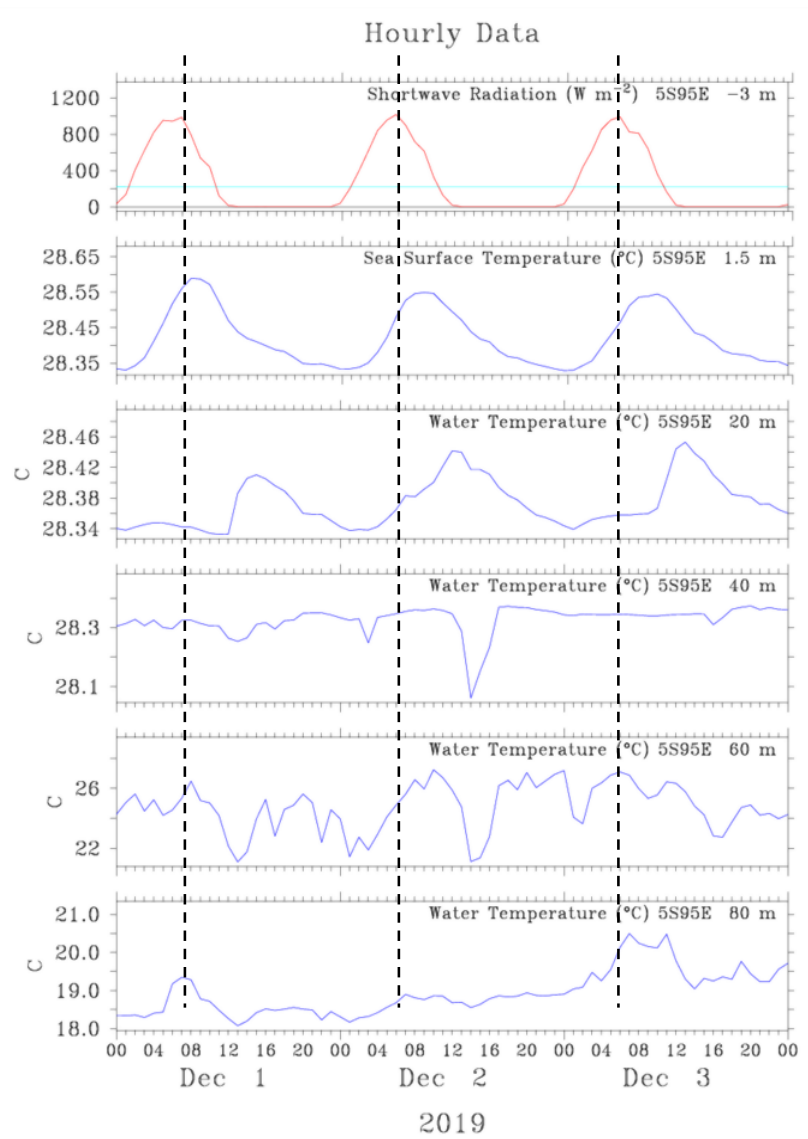

(a)

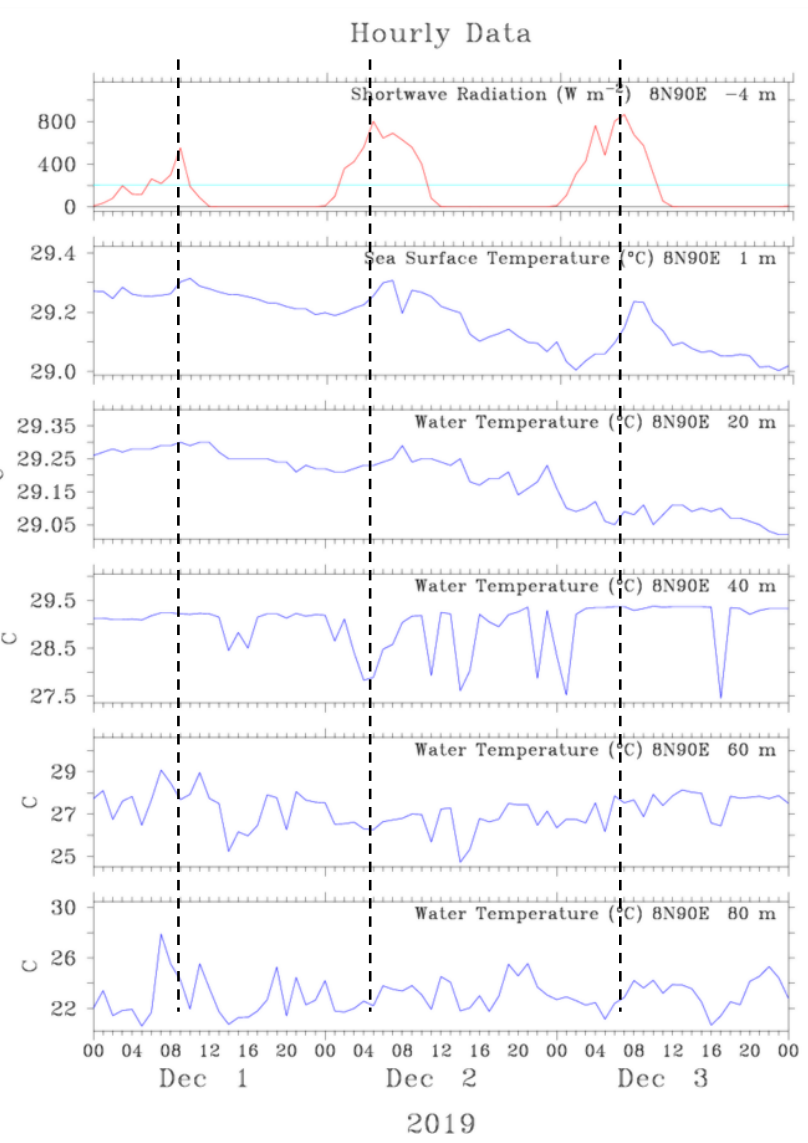

(b)

Figure 2. Daily observations of SWR using a pyranometer and sea temperature at the mooring buoy (a) $5^{\circ} \mathrm{S} 95^{\circ} \mathrm{E}$ and (b) $8^{\circ} \mathrm{N} 90^{\circ} \mathrm{E}$ in the Indian Ocean (dashes line is peak of daily SWR). source: pmel.noa.gov 
because of the higher latent heat release, and vice versa (Wirasatriya et al., 2019). This condition causes the northern region to have a different sea temperature pattern compared to the southern region. In addition, the low SWR intensity reduces heating in the surface area. As for the layer with a depth of $40 \mathrm{~m}$ to $80 \mathrm{~m}$, the pattern of sea temperature does not follow the daily SWR pattern, which means that the deep sea temperature response absorbs SWR heat only up to $20 \mathrm{~m}$. The temperature changes that occur at a depth of 40 to $80 \mathrm{~m}$ are influenced by stirring activity due to differences in density and temperature of each layer. Based on these conditions, the monthly variation between SWR and SST will be explained and its relationship with the IOD phenomenon.

Before the model data will use to analyze the monthly variations, the data must compered by the observation at point $\left(5^{\circ} \mathrm{S} 95^{\circ} \mathrm{E}\right)$. The selection of this point is based on the availability of long data to get monthly data. The parameters compared were monthly SST and SWR parameters. The results of the comparison of ocean and atmospheric model data to the observation results (Figure 3) generally show very good accuracy between each other where the correlation results show almost perfect values. For the monthly SST parameter, the correlation value reached 0.98 and for the monthly SWR parameter it reached 0.87 . This suggests that the SST model of Copernicus and the DSWR ERA5 ECMWF model can replace the missing observation of mooring buoy in the Indian Ocean and it can spatially describe the monthly variations very well.

Based on the seasonal SST and SWR variations in the Indian Ocean (Figure 4), warm pools are generally located in the East Indian Ocean while SWR intensity is on the west side of

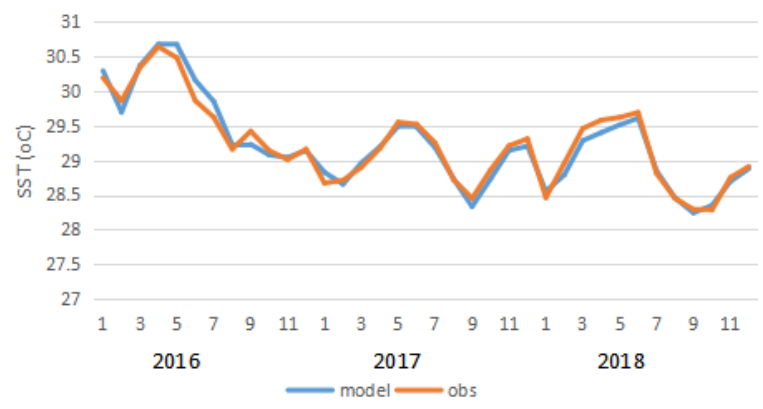

(a) the Indian Ocean. This condition indicates that there is no direct relationship between the increase in SWR to SST as a whole season. However, when viewed in detail each season, generally changes in SST in the north and south equator follow the pattern of seasonal changes in SWR. This can be seen in December-January-February (DJF) and June-July-August (JJA). In the DJF period, the highest SWR intensity was in the south of the equator and an increase in SST also occurred in that area. Meanwhile, in JJA, the highest SWR is in the north of the equator followed by SST which warms up in the region. As for the March-April-May (MAM) period and September-October-November (SON) SST spread almost evenly throughout the waters of the Indian Ocean. The spread of SST to the western region of the Indian Ocean is generally due to the existence of the southern equatorial current which always moves to the west of the Indian Ocean (Schott et al, 2009) where the increase in SST over the equatorial region has an impact on weakening the monsoon (Du and Xie 2008; Hoerling et al., 2004) and during the MAM and SON seasons the west and east monsoons weaken in the tropics.

The increasing SST in the equatorial region of the Indian Ocean has no direct relationship with changes in SWR. SST changes are more dominantly influenced by physical processes and oceanographic dynamics that occur in these waters. In addition, the low SWR in the eastern Indian Ocean was due to the large amount of cloud growth that occurred in response to the increase in SST in the region. The large number of particulates in the air such as clouds causes the high SWR scattering and absorption process by these particles, thereby reducing the heating intensity or SWR.

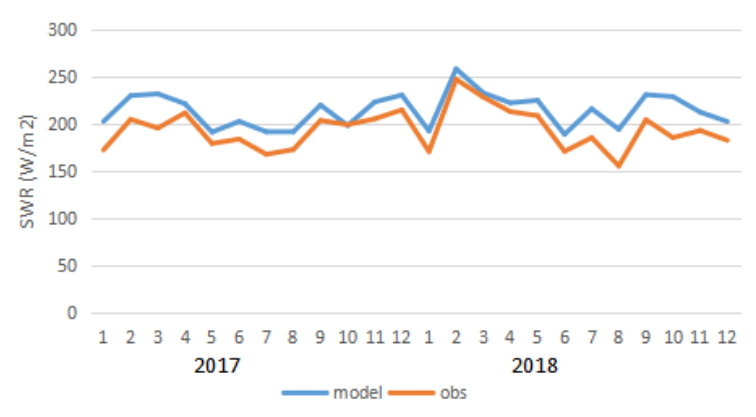

(b)

Figure 3. Comparison between (a) SST and (b) SWR models with the observational data at $5^{\circ} \mathrm{S} 95^{\circ} \mathrm{E}$ in 2016-2018. 


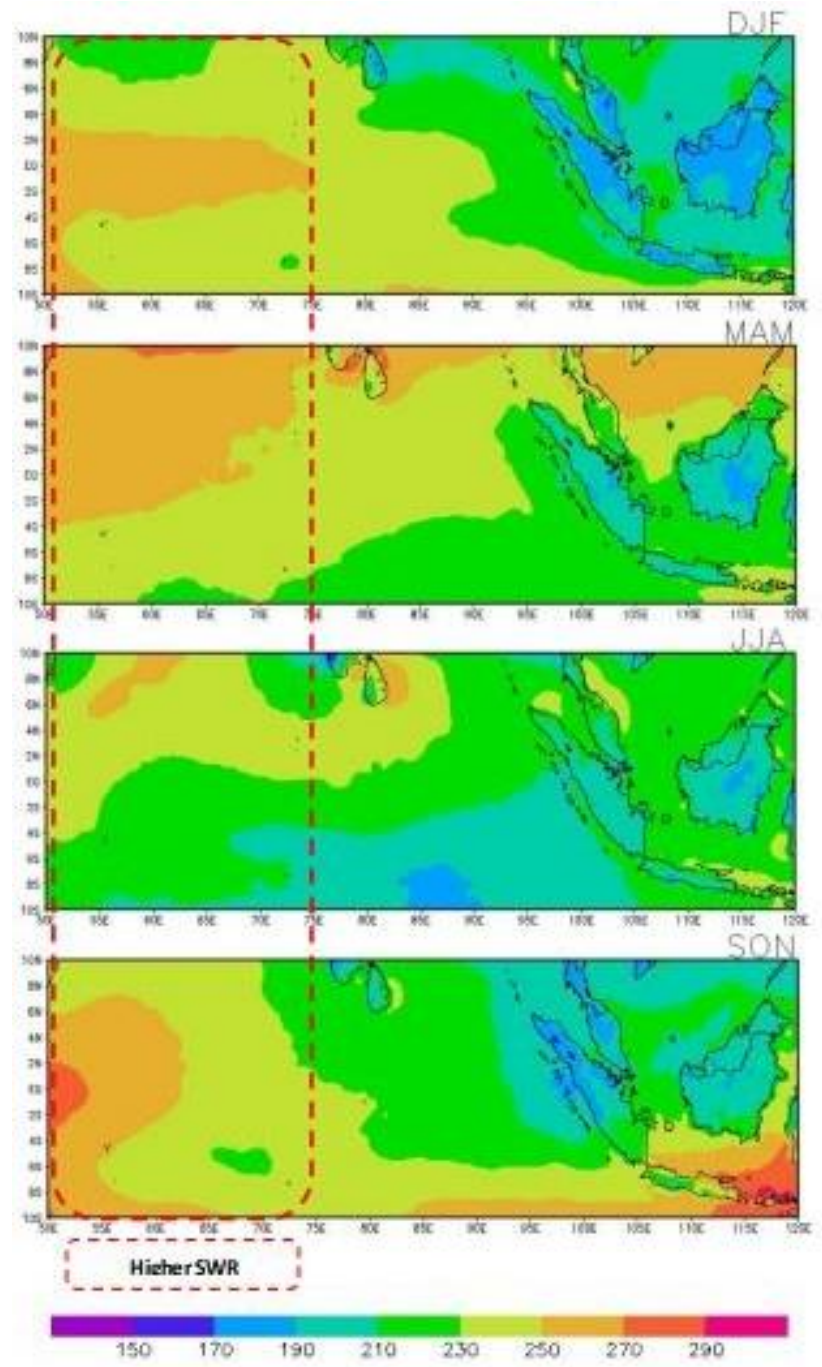

(a)
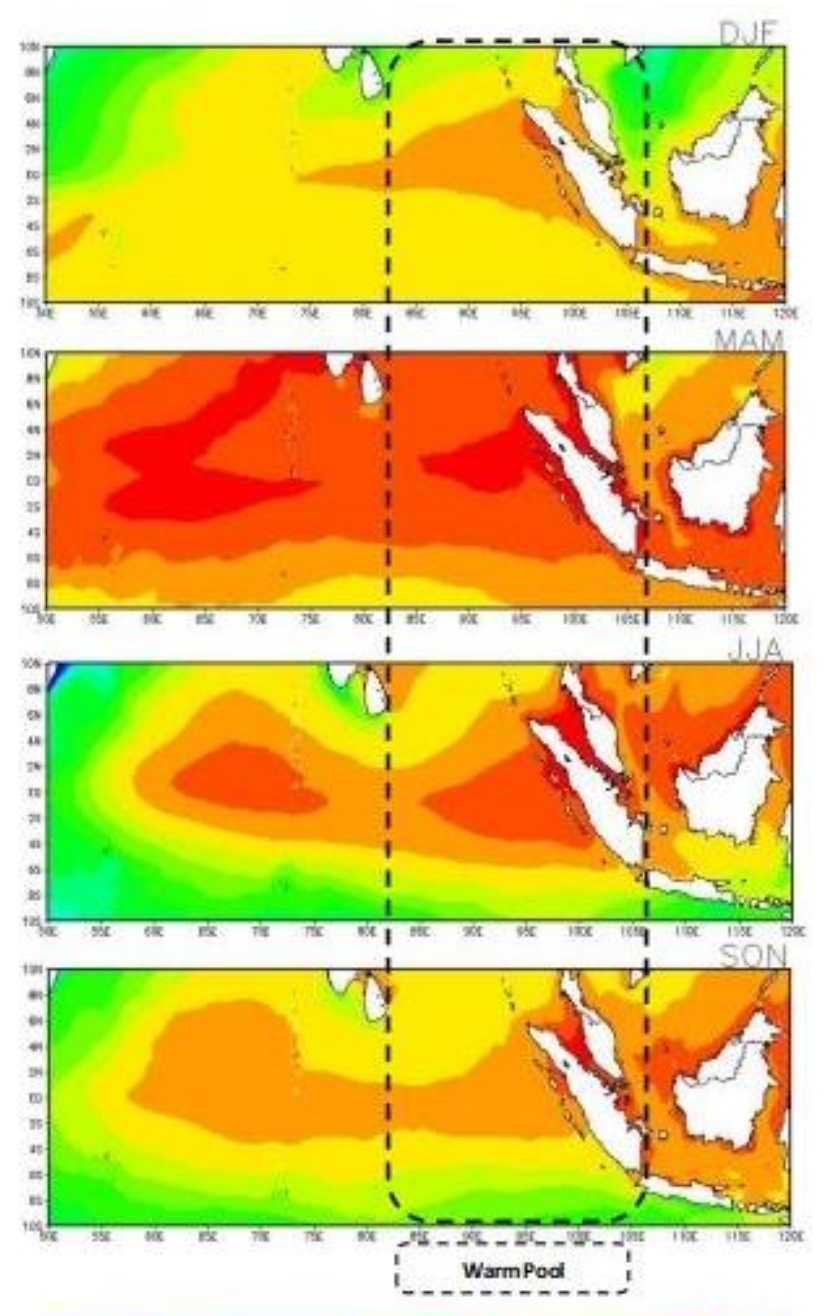

$\begin{array}{lllllllllllll}24 & 26.5 & 25 & 25.5 & 26 & 26.5 & 27 & 27.5 & \text { at } & 28.5 & 29 & 28.5 & 50\end{array}$

(b)

Figure 4. Seasonal variations of (a) SWR and (b) SST in Indian Ocean based on 2009-2018 monthly averages. Black lines lines show the average of warm pool and the red lines show the average of higher SWR.

The monthly pattern of SST and SWR in the Indian Ocean is clearly illustrated by the hovmoller diagram (Figure 5) where changes in SST and SWR form a visible wave of increasing and decreasing both of these parameters. In general, the SST warming peak in the Indian Ocean region occurs in April-July following the seasonal pattern and experiences a decrease in temperature in November-January. The highest average temperature in the Indian Ocean for the last 10 years was $30.6^{\circ} \mathrm{C}$ in April 2016 and the lowest was $27.8^{\circ} \mathrm{C}$ in January 2011 . The SWR pattern shows conditions that are opposite to the SST pattern where along with the increase in SST, there is a decrease in SWR. in the region. The increase in SWR was generally concentrated in the western Indian Ocean region and in certain cases there was an increase in SWR in the eastern Indian Ocean, especially in 2015. If it is related to the IOD event, in general changes in SST and SWR in the Indian Ocean are related based on this diagram.

In 2010 and 2016 the SST pattern had a similarity where there was an increase in SST in the Indian Ocean region, especially in the eastern part of the Indian Ocean. If this condition is related to DMI (Figure 6), then in that year a negative IOD phenomenon occurs. In general, the negative IOD indicates an increase in SST in the eastern Indian 
Ocean which results in a lot of cloud growth and an increase in rainfall in the region. The increase in SST occurred from June to October in each year of occurrence. Along with the increase in SST, the SWR parameter has decreased in these years. Furthermore, in 2012 and 2015 there was a similar pattern where there was an increase in SST in the western Indian Ocean. Based on the DMI, there was a positive IOD phenomenon in that year. In general, positive IOD indicates an increase in SST in the West Indian Ocean and a decrease in SST in the eastern region (Vinayachandran et al., 2009). This will certainly increase the SWR intensity in the eastern region in these years.

The relationship between SWR and SST variations which are IOD phenomena in general is quite visible in the diagram. However, it is clear that the relationship between these variations is seen in the graph between the SWR anomaly (SWRA) and DMI (Figure 6). DMI is obtained from the SST anomaly difference in the West Indian Ocean box $\left(10^{\circ} \mathrm{S}-10^{\circ} \mathrm{N}\right.$ and $\left.50^{\circ} \mathrm{E}-70^{\circ} \mathrm{E}\right)$ and the East Indian Ocean box $\left(10^{\circ} \mathrm{S}-0^{\circ} \mathrm{N}\right.$ and $90^{\circ} \mathrm{E}-$ $110^{\circ} \mathrm{E}$ ) (Saji et al, 1999). Based on the box, the

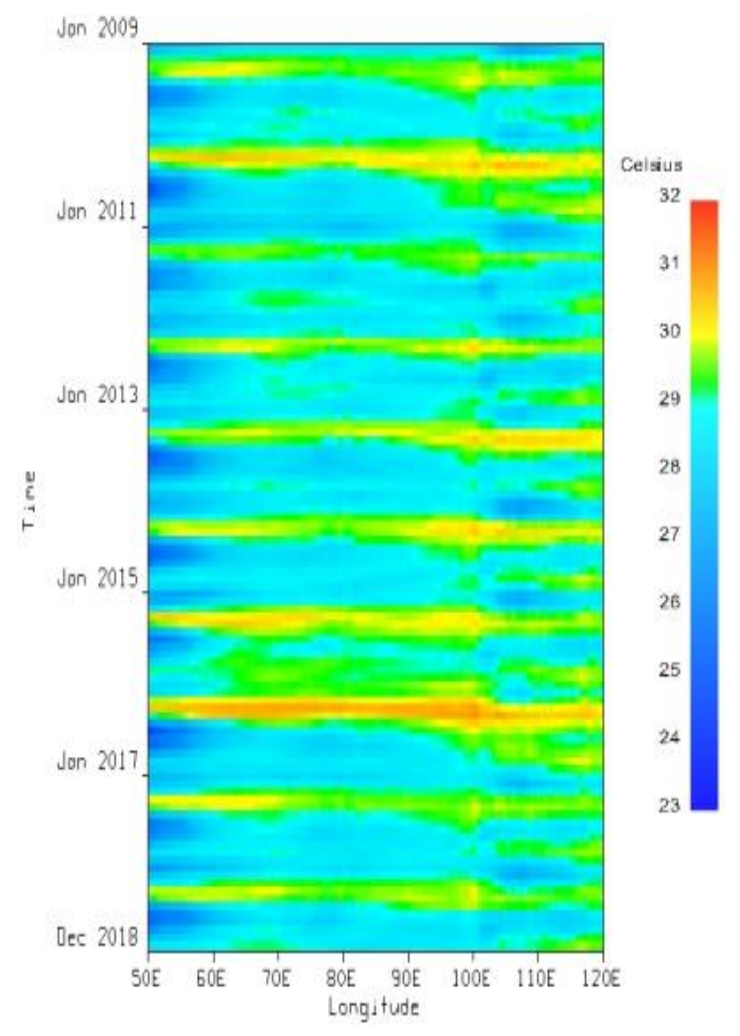

(a)
SWRA average in the area is then made to see the relationship between SWRA and DMI. SWRA generally follows the DMI pattern in eastern cities (Figure 6, a) where a positive index will increase the SWR intensity in the region and a negative index will decrease its intensity. Conversely, the SWRA pattern is opposite to the DMI in the west box (figure 6, b). Positive IOD will decrease the SWR intensity and negative index will increase the intensity. This is of course closely related to the increase and decrease in cloud growth in these waters.

As Spatially, the process of the occurrence of positive and negative IOD phenomena is well illustrated by SWRA. It is assumed that the SWRA value here has a relationship with cloud growth in the Indian Ocean region where the level of cloud cover affects the level of SWR recorded on the surface. From that figure, there was a positive SWRA movement from the West Indian Ocean to the East Indian Ocean in early 2015. The peak of the increase in SWRA occurred in JJA to SON which indicates that during that period, the surface area received a lot of warming from the SWR.

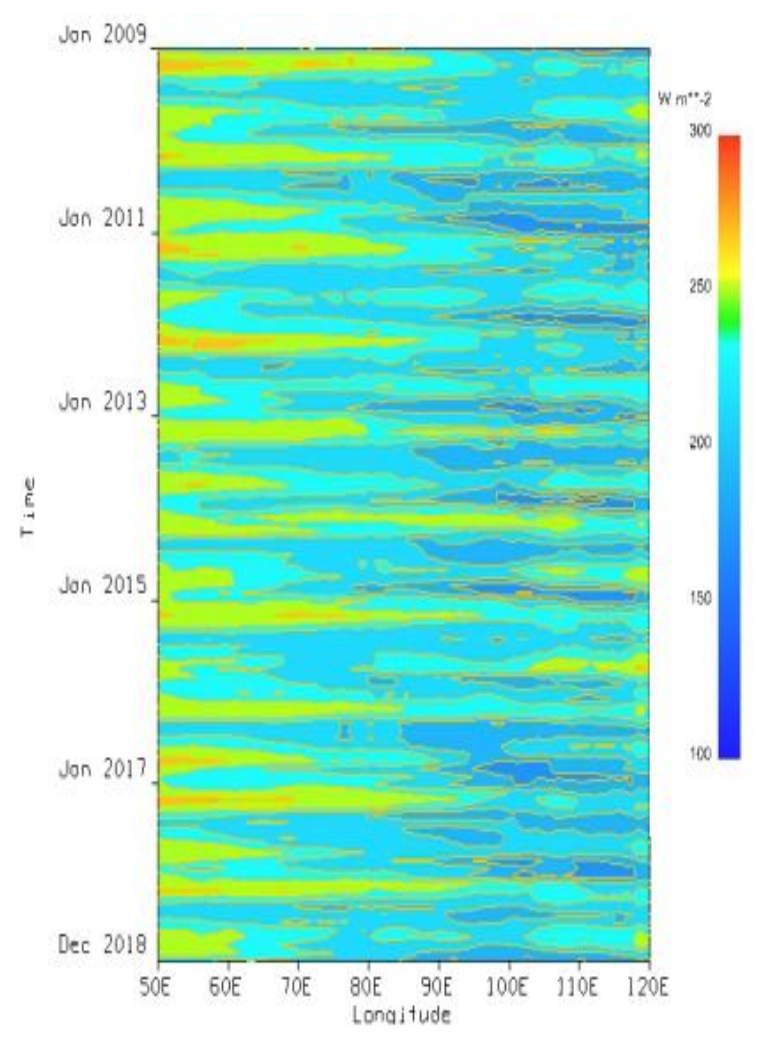

(b)

Figure 5. Hovmoller chart of (a) SST and (b) SWR monthly variations in the Indian Ocean region $\left(10^{\circ} \mathrm{S}\right.$ $\left.10^{\circ} \mathrm{N}-50^{\circ} \mathrm{E} 120^{\circ} \mathrm{E}\right)$ 


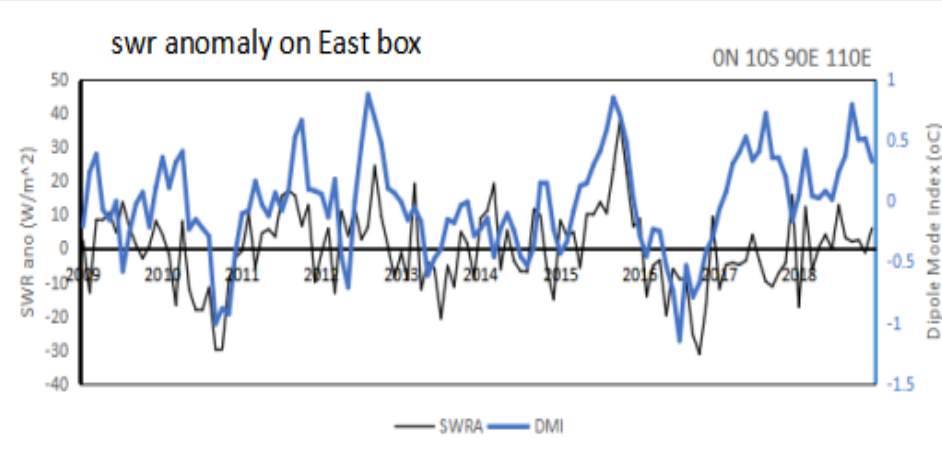

(a)

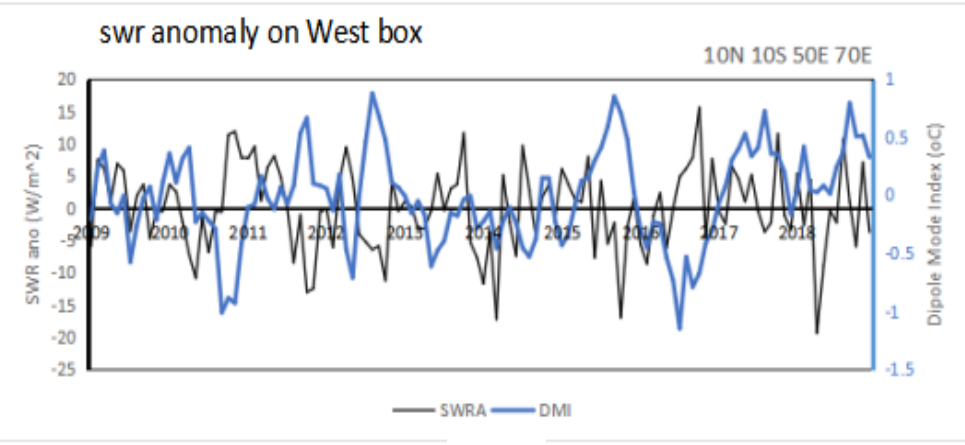

(b)

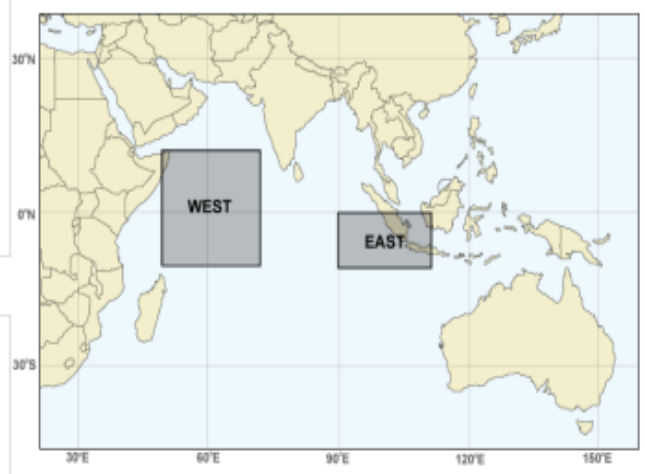

(c)

Figure 6. Comparison between SWRA and DMI in (a) east box and (b) west box. According to (c) regional determination of the DMI (Saji et al, 1999). Determination of DMI using NOAA NCDC ERSST.v.5. (http://iridl.ldeo.columbia.edu/)
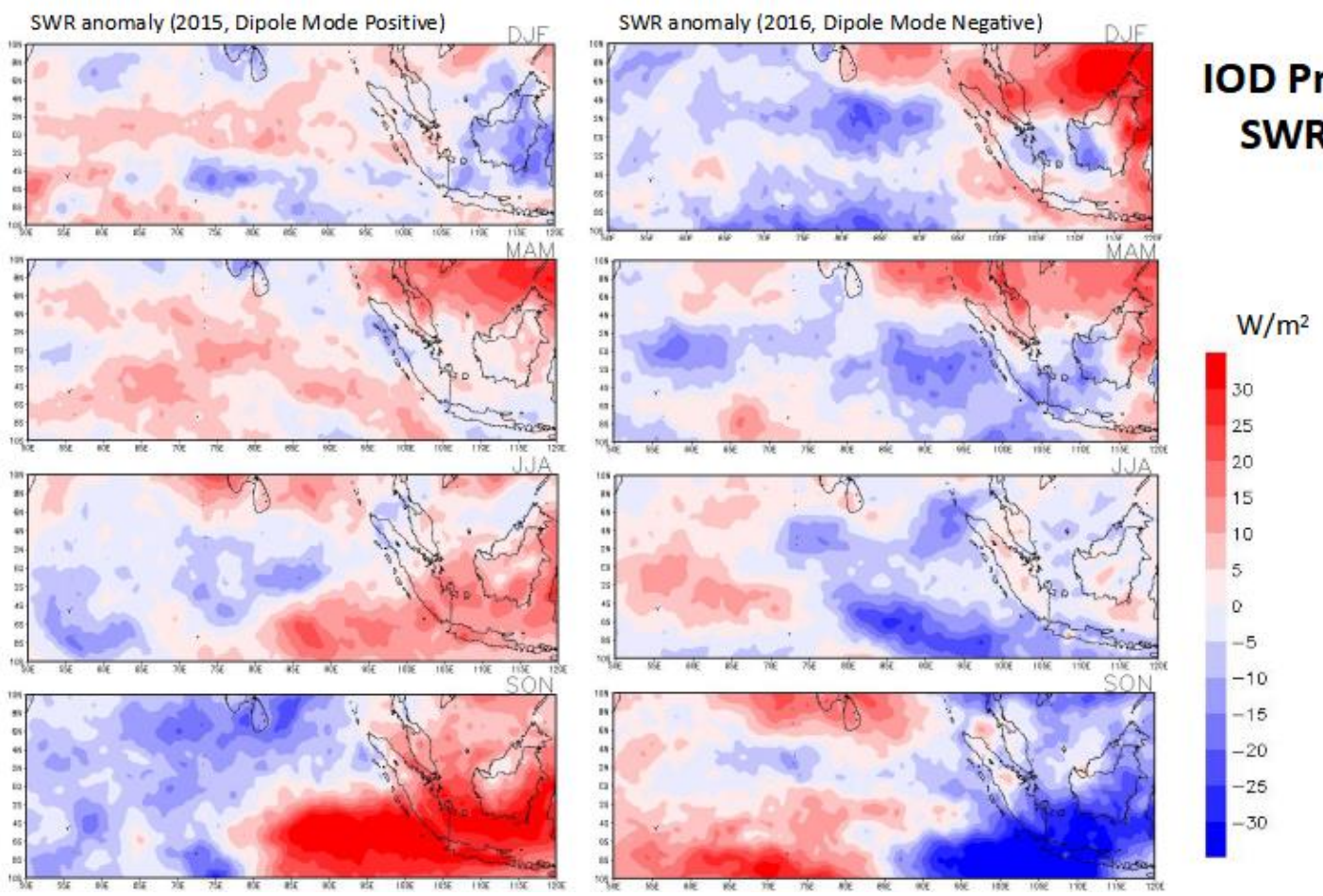

Figure 7. The process of positive IOD and negative IOD phenomena as described by SWR 
Likewise, in 2016 when there will be a negative IOD phenomenon, there will be a positive transfer of SWRA to the western part of the Indian Ocean. This process takes place as in the positive IOD phenomenon where the negative SWRA slowly moves towards the East Indian Ocean. The lowest decrease in SWRA occurred in MAM until its peak in SON month. This condition can be related to the very extensive cloud cover in the East Indian Ocean, including Indonesian waters. The concentration of the increase and decrease in the value of the SWRA in the Eastern Indian Ocean is concentrated in the southern region of the equator of the Indian Ocean. If associated with seasonal patterns in Indonesia, the positive IOD will extend the dry season and the rainy season will extend to the negative IOD (Fadholi, 2013), especially in the southern regions of the Indonesian equator

\section{CONCLUSIONS}

Based on a daily pattern, the SWR peak in the Tropical Indian Ocean region occurs at $4-6$ UTC and affects ocean temperatures to a depth of $20 \mathrm{~m}$. The sea temperature lag in response to SWR is around $2-3$ hours at the surface area and 4 hours at a depth of $20 \mathrm{~m}$. Depths of $40 \mathrm{~m}$ etc. do not respond directly but transfer heat through the stirring mechanism. Warm pools are generally located in the eastern Indian Ocean while the center of warming is very strong in the western Indian Ocean. Although seasonal SWR is not directly proportional to sea surface temperature, SWR has a fairly strong reciprocal effect on sea surface temperature. There is a good connection between the SWR anomaly changes and the IOD phenomenon.

\section{ACKNOWLEDGEMENTS}

We are very grateful to the crew and team of the INA-PRIMA program in 2019 who have sailed together to support the availability of data in the Indian Ocean. Thanks are also conveyed to PMEL NOAA and BMKG who organized this program and STMKG as the sponsor for participation in the ICTCRED in 2020 so that this research can be published properly.

\section{REFERENCES}

de Boyer Montégut, C., Madec, G., Fischer, A.S., Lazar, A. and Iudicone, D., 2004. Mixed layer depth over the global ocean: An examination of profile data and a profile-based climatology. Journal of Geophysical
Research: Oceans, 109(C12003):1-20. doi : 10.1029/2004JC002378

Dewi, Y.W, Wirasatriya, A, Sugianto, D.N, Helmi, M., Marwoto, J., \& Maslukah, L. 2020. Effect of ENSO and IOD on the Variability of Sea Surface Temperature (SST) in Java Sea. IOP Conf. Series: Earth and Environmental Science, $530 \mathrm{p}$

Du, Y., \& Xie, S.P. 2008. Role of atmospheric adjustments in the tropical Indian Ocean warmingduring the 20th century in climate models. Geophysical Research, Letters 35(L08712):1-5. doi : 10.1029/2008GL033631

Fadholi A. 2013. Studi Dampak El Nino Dan Indian Ocean Dipole (IOD) Terhadap Curah Hujan Di Pangkalpinang. Jurnal Ilmu lingkungan, 11:43-50

Hoerling, M., Hurrell, J., Eischeid, J. \& Phillips, A. 2006. Detection and attribution of twentiethcenturynorthern and southern African rainfall change. Journal of climate, 19(16):3989-4008

Huang, Y., Guo, B. \& Subrahmanyam, M.V., 2018. Shortwave Radiation and Sea Surface Temperature Variations over East and West Tropical Pacific Ocean. Open Access Library Journal, 5(8):1-9.

Kalogirou, S. 2009. Solar Energy Engineering : Processes And Systems. Elsevier's Science \& Technology. Academic Press.

Klassen, S. and Bugbee, B., 2005. Shortwave radiation. Micrometeorology in agricultural systems, 47:43-57.

Manjunatha, B.R., Krishna, K.M. and Raju, Y.N., 2015. Relationship among sea surface temperature, ENSO and Indian Ocean dipole in the Indian Ocean: a clue to recognizing convective systems. The Open Oceanography Journal, 8(1):20-27.

Putra A.P, Atmadipoera A.S., \& Pariwono J.I,. 2020. Response Of Sea Surface Temperature And Chlorophyll-A On Enso And Iodm Events In The Tropical Indo-Pacific Region. Jurnal Ilmu dan Teknologi Kelautan Tropis, 12(1):167-182

Saji, N.H., Goswami, B.N., Vinayachandran, P.N. \& Yamagata, T., 1999. A dipole mode in the tropical Indian Ocean. Nature, 401(6751): 360-363.

Schott, F.A., Xie, S.P. \& McCreary Jr, J.P., 2009. Indian Ocean circulation and climate variability. Reviews of Geophysics, 47(1):1-46 doi: 10.1029/2007RG000245 
Sukresno, B. 2010. Empirical Orthogonal Functions (EOF) Analysis of SST Variability in Indonesian Water Concerning with ENSO and IOD. International Archives of the Photogrammetry. Remote Sensing and Spatial Information Science Journal. 38(8):116-121

Vinayachandran, P.N., Francis, P.A. and Rao, S.A., 2009. Indian Ocean Dipole: Processes and Impacts. Current Trends in Science. pp.569-589

Wild, M. \& Liepert, B., 2010. The Earth Radiation Balance as Driver of The Global Hydrological
Cycle. Environmental Research Letters, 5(2):p025203

Wirasatriya, A., Sugianto, D.N., Helmi, M., Maslukah, L., Widiyandono, R.T., Herawati, V.E., Subardjo, P., Handoyo, G., Haryadi, M.J., Suryoputro, A.A.D. \& Atmodjo, W., 2019. Heat flux aspects on the seasonal variability of sea surface temperature in the Java Sea. Ecology, Environment and Conservation. 25(1):434-442. 